\title{
Current account deficits and implications on Romanian economy
}

\author{
Sorin Cristian NIȚ̆ \\ Bucharest University of Economic Studies, Bucharest, Romania \\ nitasorincristian@gmail.com \\ Marilena Ionica RADULICĂ \\ University of Pitesti, Pitești, Romania \\ radulica.marilena@yahoo.com \\ Mihai DORNEANU \\ Bucharest University of Economic Studies, Bucharest, Romania \\ mdorneanu7@gmail.com
}

\begin{abstract}
The current account deficit is becoming a concerning matter with regards to the Romanian's economy growth's perspectives, also holding the attention of international financial institutions and rating agencies. Deficits and surpluses with regards to the current account are, to some extent, normal features of each economy and, by definition, do not constitute macroeconomic imbalances that need to be corrected immediately. Even so, by the international 's standards Romania's current account deficit is a significant one. This paper aims to analyze the reason behind the increased current account deficit and also issue a series of recommendations in order for the economy to function as close to it's potential as possible.
\end{abstract}

Keywords: current account, economic growth, exports, imports, deficits

\section{Introduction}

The current account plays a very important role in the policymaker's analysis of economic developments. Considering the fact that a country`s current account balance is computed as the difference between exports and imports it reflects the totality of the resident's transactions with the foreign environment with regards to goods and services. Current account deficits are characteristic of emerging economies, given the need for capital input. Thus, the deterioration of the trade balance due to the larger investments (accelerating the imports of capital goods) is not a major problem, since the transfer of technology can support the productivity advance and implicitly of the longterm exports. However, the macroeconomic picture may worsen if the imbalances become excessive.

\section{Literature review}

By looking at the inter temporal approach, current account deficits are explained as the outcome of forward-looking dynamic saving and investment decisions driven by the expectation that productivity, interest rates, government expenditure and other factors will grow. Within this framework, the current account balance behaves as a buffer against shocks in demand or supply. (Sachs, 1981; Obstfeld \& Rogoff, 1995, 1996; Ghosh, 1995; Razin, 1996).

If looked at from their origin point of view, shocks may be country wide or global, and telling them apart is very important considering the fact that literature finds global productivity shocks having a smaller impact on current account deficits than country specific shocks. (Glick \& Rogoff, 1995; Razin, 1996). In a similar way, the persistence of shocks may generate different responses on the current account balance. For example, a permanent shock on production may generate an investment surge which would automatically have an impact on savings (in a negative 
way). If the same shock would be temporary, the current account may move to surplus, as no investment response to a temporary shock would be required (Glick \& Rogoff, 1995; Obstfeld \& Rogoff, 1995). Also, the timing of the shocks, with regards to the fact if they are expected or not in the economy, may also have an impact on changes in the current account balances. In this paper, analyze the main determinants of the Romanian current account deficits and issue a series of recommendations

PICBE | 996

In this paper, we intend to go into detail with regards to the main determinants of the current account balances in Romania and to observe the reason behind the widening current account deficit in the past years.

\section{Methodology}

For the purpose of this paper, we have collected data from Eurostat and BNR for Romania and countries with a similar economic structure as Romania. We compared the evolution of the current account balance and other indicators for the selected countries and we went further in detail in order to observe the main reasons behind the persistency of the Romanian current account deficit. We have also issued a series of recommendations for the future in order for Romania to reduce the current account deficit and maintain a strong and sustainable economic growth.

\section{Results and discussions}

With the appearance of the financial crisis, the current account deficit (expressed as a share of GDP) experienced an adjustment, from $13.6 \%$ in 2007, to the lowest level in 2014 (-0.7\% of GDP). However, since 2015, it has been on a downward trend, reaching a level of $-4.5 \%$ of GDP at the end of last year. The present level can be considered a moderate one, compared to the period before the crisis, when the current account deficit as a share of GDP was expressed in 2 figures $(\sim 14 \%$ of GDP in 2007 and $~ 12 \%$ of GDP in 2008).

By international standards, however, Romania's deficit is a significant one. Thus, the lower reference limit set by the European Commission as a performance indicator for the member countries of the European Union is -4\% (3-year average). Given the level of the deficit in the last year, Romania risks exceeding this threshold if it maintains its increasing trajectory in recent years.

Currently the unfavorable external position of Romania is substantially above those registered by the majority of peer-countries (comparable states in the region):

Table 1: Current account balance expressed as \% of GDP

\begin{tabular}{|l|c|c|c|c|c|c|c|c|c|c|c|c|}
\hline & 2007 & 2008 & 2009 & 2010 & 2011 & 2012 & 2013 & 2014 & 2015 & 2016 & 2017 & 2018 \\
\hline Romania & $\mathbf{- 1 3 , 6}$ & $\mathbf{- 1 1 , 4}$ & $\mathbf{- 4 , 7}$ & $\mathbf{- 5 , 1}$ & $\mathbf{- 5 , 0}$ & $\mathbf{- 4 , 8}$ & $\mathbf{- 1 , 1}$ & $\mathbf{- 0 , 7}$ & $\mathbf{- 1 , 2}$ & $\mathbf{- 2 , 1}$ & $\mathbf{- 3 , 2}$ & $\mathbf{- 4 , 5}$ \\
\hline Bulgaria & $-23,9$ & $-22,0$ & $-8,3$ & $-1,7$ & 0,3 & $-0,9$ & 1,3 & 1,2 & 0,0 & $\mathbf{2 , 6}$ & 3,1 & 4,6 \\
\hline $\begin{array}{l}\text { Czech } \\
\text { Republic }\end{array}$ & $-4,6$ & $-1,9$ & $-2,3$ & $-3,6$ & $-2,1$ & $-1,6$ & $-0,5$ & 0,2 & 0,2 & $\mathbf{1 , 6}$ & 1,7 & 0,3 \\
\hline Hungary & $-7,1$ & $-7,0$ & $-0,8$ & 0,3 & 0,8 & 1,7 & 3,8 & 1,5 & 2,7 & $\mathbf{6 , 1}$ & 2,8 & 0,3 \\
\hline Poland & $-6,3$ & $-6,7$ & $-4,0$ & $-5,4$ & $-5,2$ & $-3,7$ & $-1,3$ & $-2,1$ & $-0,6$ & $\mathbf{- 0 , 5}$ & 0,2 & $-0,6$ \\
\hline Slovakia & $-5,9$ & $-6,5$ & $-3,4$ & $-4,7$ & $-5,0$ & 0,9 & 1,9 & 1,1 & $-1,7$ & $\mathbf{- 2 , 2}$ & $-2,0$ & $-2,5$ \\
\hline
\end{tabular}

Source: Eurostat 
By taking 2016 as a base year for the comparison, it is visible that Romania's deficit increased from -2.1 in 2016 to -4.5 in 2018, an increase of $2.4 \%$ of GDP, while other peer countries maintained a much better line. In the case of Poland current account deficit in 2016 accounted for $-0.6 \%$ of GDP (worsening from $-0.5 \%$ in 2016 ), Slovakia: $-2.5 \%$ (worsening from $-2.2 \%$ in 2016 ), Czech Republic: $+0.3 \%$ (decreasing from the value of $+1.6 \%$ in 2016 ), Hungary: $+0.3 \%$ (decreasing from the value of $+6.1 \%$ in 2016); Bulgaria: $+4.6 \%$ (improvement from the value of $+2.6 \%$ in 2016). The majority of the states taken into account when performing the analysis, although witnessing a visible deterioration as opposed to 2016, still run current account surpluses with the exception of Romania, Poland and Slovakia.

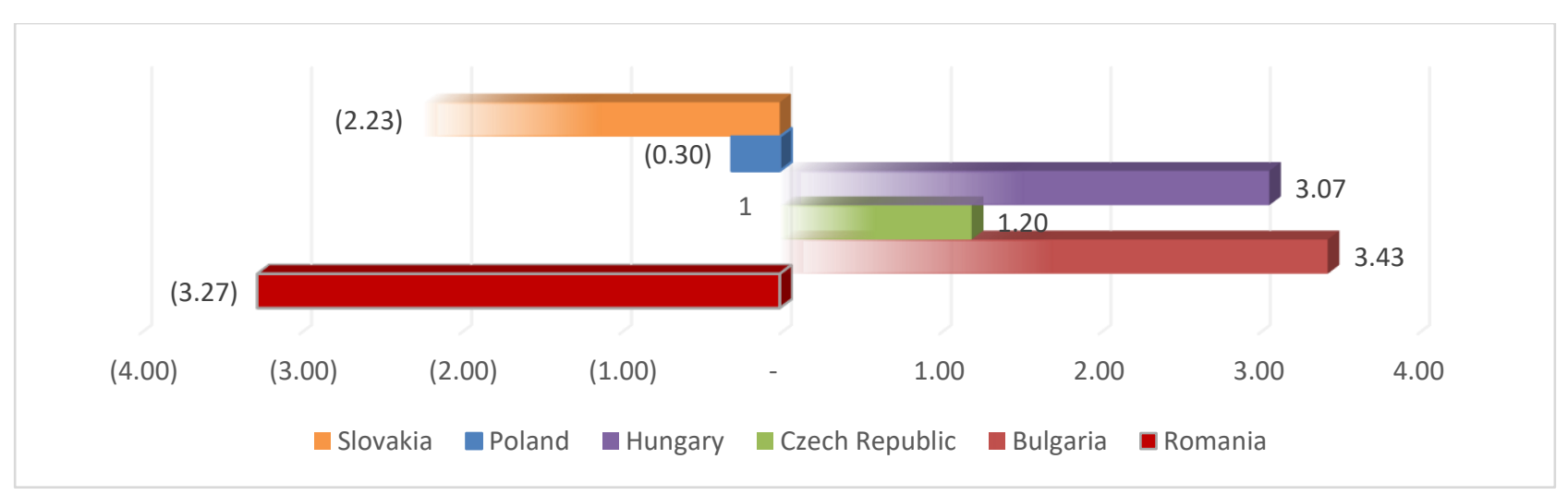

Graph 1: Current account balance expressed as \% of GDP (avg. 2016-2018)

Source: Eurostat

In Romania, the current account deficit is mainly generated by the negative balance of the trade balance (the balance of goods). Although other ECE countries (Bulgaria, Hungary, Poland) are experiencing trade deficits that negatively affect the current account balance, in RO this impact is greatest, given that, at the level of 2018 , the balance of goods deficit was by $7.3 \%$ of GDP.

By comparison, in 2018 Bulgaria and Poland recorded trade balance deficits of $4.1 \%$ of GDP, respectively $1 \%$ of GDP. On the other hand, the Czech Republic and Slovakia have trade surpluses of $4.1 \%$ and $0.1 \%$ of GDP, respectively.

Regarding the balance of services it recorded surpluses, both in Romania and in the other ECE states analyzed being observed that Romania's surplus (4.1\% of GDP) is lower than recorded in Bulgaria ( $6.2 \%$ of GDP), Hungary (5.8\% of GDP), Poland (4.5\% of GDP), but higher than the Czech Republic (2.3\% of GDP) and Slovakia ( $0.9 \%$ from GDP).

In the category of primary income, Romania, like all other countries analyzed, has a negative balance, given that this category includes investment income, which translates into outflows of funds from the country, provided that the net foreign investments are positive (a feature of developing countries). The negative balance of primary incomes is the highest in the Czech Republic (-5.3\% of GDP), followed by Poland and Hungary (each $-3.8 \%$ of GDP), Romania ($2.5 \%$ of GDP), Slovakia ( $-2 \%$ of GDP) and Bulgaria (-1\% of GDP).

Regarding the balance of secondary income, Romania has always registered a positive balance, which has gradually decreased from 2006 to the present, reaching 1.2\% of GDP in 2018 . While Bulgaria records a similar situation, the Czech Republic, Hungary, Poland, and Slovakia have a negative balance of secondary income balance. 


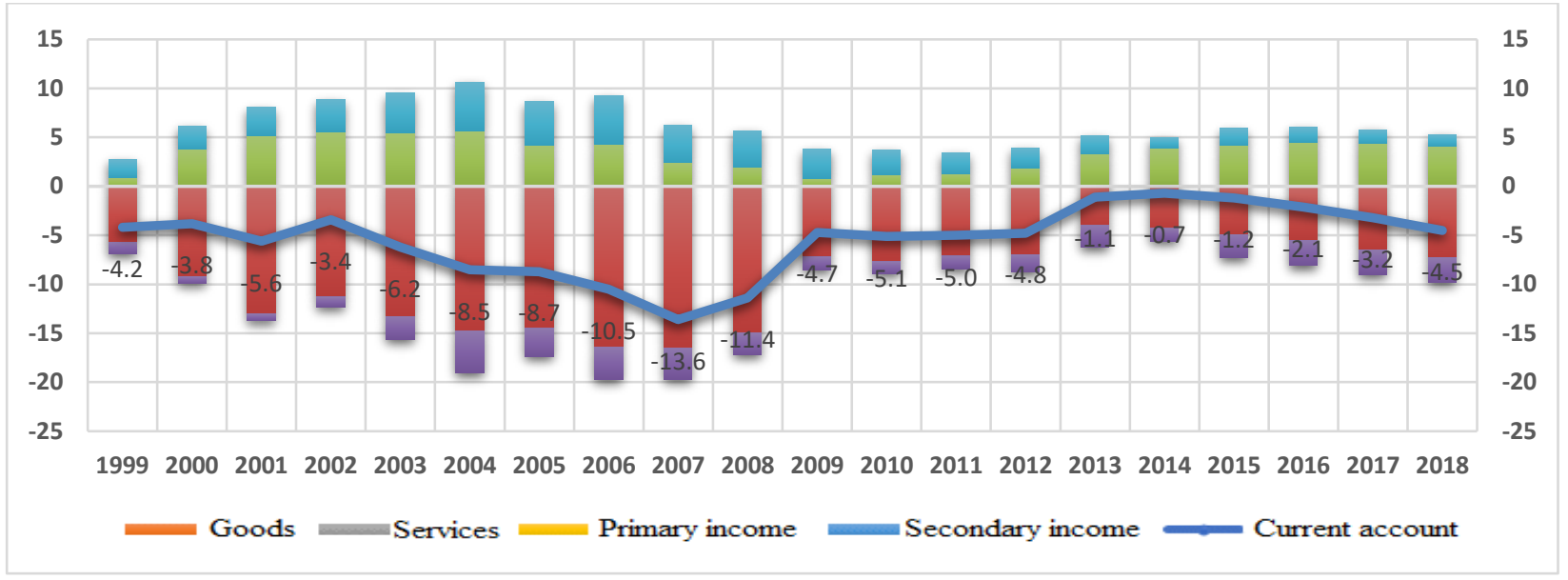

PICBE $\mid 998$

Graph 2: Current account structure - 1999 - 2018 expressed as \% of GDP

Source: Eurostat

Analyzing the period 2002-2018, we can observe some defining developments for the present situation of the trade balance, as follows:

- Increasing the trade deficit in the category "chemicals" from 1.35 billion euros in 2002, to 7.56 billion euros in 2018. (The most important categories that determined this dynamic are: pharmaceuticals and plastics). Romania ranks the 3rd largest deficit in the category "chemicals", being outpaced only by Poland and Spain, these being countries with a much more developed industry sector.

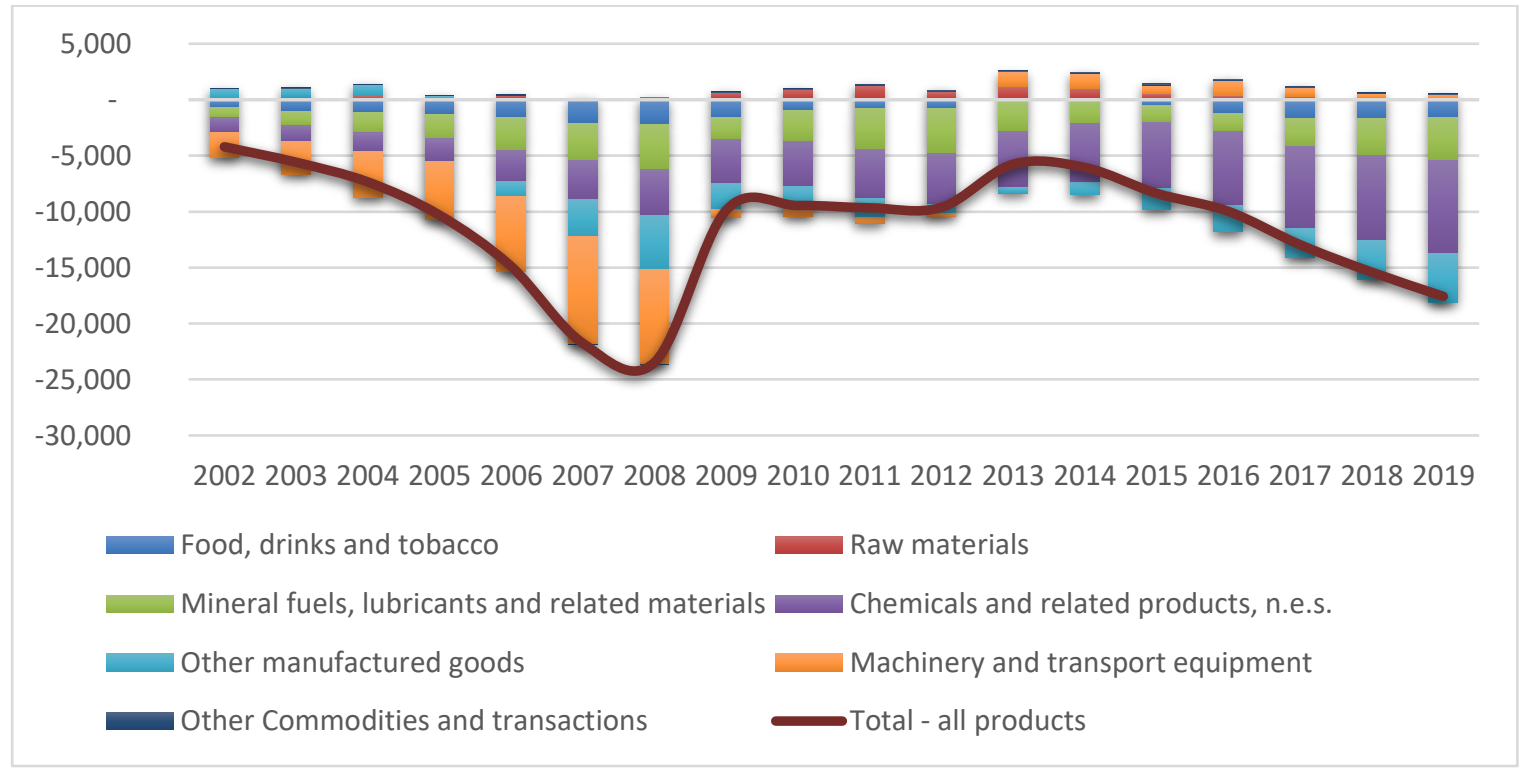

Graph 3: Evolution of the trade balance in the period 2002-2018 (EUR million) - according to the International Trade Standard Classification (SITC)

Source: Eurostat

According to the analysis of the trade deficit of the Romanian economy carried out by the Economic Programming Council in August-September 2018, it appears that the medicine group is 
second in importance (after the oil subgroup) regarding the contribution to the trade deficit of Romania, with a value of $13.3 \%$ of the total deficit registered in 2017. In 2017, the imports of medicines represented the third category regarding the total imports of Romania, by car components ( 3 billion euros), oil ( 2.7 billion euros) and before the total car imports ( 2.1 billion euros).

- Reversing the trend in the category "Machinery and transport equipment" from the trade deficit in the period 2002-2012 (maximum point of 9.61 billion euros in 2007 - when it generated more than a third of the trade deficit), to the commercial surplus in 2013-2018 period (maximum point of 1.35 billion euros in 2014). Regarding the Romanian automotive industry, a reversal of the trend from 2002-2008 is visible, when Romania, based on the accelerated growth of revenues, generated an annual average trade deficit of 5.6 billion euros in the category "Machines and equipment transport". The turning point was the economic crisis, the trade deficit being reduced in a single year from -8.46 billion euros to -737 million euros, due to a sharp drop in consumption. Starting with 2013 , the automotive industry generated an average annual surplus of approx. 1 billion euro.

- Reversing the trend in the category "Other industrial goods" from the trade surplus in the period 2002-2005, to the trade deficit in the period 2006-2018.

- d) Running a trade surplus in the "Raw materials" category (maximum point of 1.28 billion euros in 2011).

As for the balance of services, a surplus is recorded that plays the most important role in balancing the current account, growing steadily in volume after 2012. The components that support the surplus continue to remain road transport services, telecommunications, IT and information services (IT\&C), those for processing goods, as well as business services (consultancy, technical, etc.). Tourism / travel services represent the component with the most significant negative contribution to the balance of services ( 1.3 billion euros in 2018 , increasing by about 0.5 billion lei compared to 2017). Against the background of the sharp increase in population income, this component has led to a decrease in the surplus of the services balance, almost completely canceling the growth in the IT\&C sector. ( Data source: NBR ). With regards to the trannsport industry, a potential major risk that may affect the most important component of the Balance of Services is the adoption of the Mobility Package by the European Parliament. The proposals included in the mobility package were made based on the growing protectionism of the Western EU Member States meeting within the Road Alliance, and the Romanian and East European carriers will be the most affected by the proposed measures, which will lead to a significant increase in costs. their operation and the restriction of international road transport operated by them within the EU. The NBR has developed a scenario that estimates a negative impact of 1 billion euros.

\section{Export competitive analisys}

By making a competitive analisys on exports it is noticeable that despite rising wage costs, Romania continues to gain earnings in the export market share - it has increased by $23 \%$ in the last five years (being in the top of the EU ranking, in 4th place), in line with that registered by Poland ( 25.4\%) and over the rest of Central and Eastern Europe. Also, by taking into account the fact that Romania is a developing economy, the increase in the wage costs is only natural.

In 2018, Romania had an export market share of $0.4 \%$ of world trade in goods and services $(0.38 \%$ in the goods category and $0.46 \%$ in the services category), similar to that of Slovakia $(0.41$ 
$\%$, above that of Bulgaria $(0.17 \%)$, but below those recorded by Poland (1.3\%), Czech Republic $(0.77 \%)$ and Hungary $(0.54 \%)$.

Table 2: Export market share (\% of total exports worldwide)

\begin{tabular}{|l|l|l|l|l|l|}
\hline & $\mathbf{2 0 1 4}$ & $\mathbf{2 0 1 5}$ & $\mathbf{2 0 1 6}$ & $\mathbf{2 0 1 7}$ & $\mathbf{2 0 1 8}$ \\
\hline BG & 0,16 & 0,15 & 0,16 & 0,17 & 0,17 \\
\hline CZ & 0,72 & 0,72 & 0,75 & 0,76 & 0,77 \\
\hline HU & 0,52 & 0,52 & 0,55 & 0,54 & 0,54 \\
\hline PL & 1,09 & 1,12 & 1,19 & 1,26 & 1,30 \\
\hline RO & $\mathbf{0 , 3 5}$ & $\mathbf{0 , 3 5}$ & $\mathbf{0 , 3 7}$ & $\mathbf{0 , 3 9}$ & $\mathbf{0 , 4 0}$ \\
\hline SK & 0,39 & 0,38 & 0,40 & 0,40 & 0,41 \\
\hline
\end{tabular}

Source: Eurostat

\section{Cost competitiveness}

Although hourly wage costs have recorded the highest growth rates in the EU in recent years, Romania still remains in the penultimate place in the European ranking in terms of hourly wage costs. It is noted that at the level of 2018, the average hourly wage cost in the economy was 6.5 euros, almost half of the level recorded in the Czech Republic and below those recorded by Hungary, Poland and Slovakia.

Table 3: Hourly wage costs per total economy (euro)

\begin{tabular}{|l|l|l|l|}
\hline & $\mathbf{2 0 1 6}$ & $\mathbf{2 0 1 7}$ & $\mathbf{2 0 1 8}$ \\
\hline BG & 4.5 & 5 & 5.3 \\
\hline RO & 5.4 & 6 & 6.5 \\
\hline HU & 8.5 & 9.4 & 9.9 \\
\hline PL & 8.5 & 9.3 & 9.9 \\
\hline SK & 10.4 & 11.1 & 11.8 \\
\hline CZ & 10.4 & 11.4 & 12.7 \\
\hline
\end{tabular}

Source: Eurostat

\section{Price competitiveness}

Price competitiveness can be assessed using the actual real exchange rate. It depends on both the evolution of the nominal exchange rate and the relative change of the domestic prices to the external ones. The decrease of the effective real exchange rate expressed in national currency / euro is equivalent to a decrease of the competitiveness, while its increase represents the improvement of the external competitiveness.

Romania recorded an increase in external competitiveness, in 2018 compared to 2014, given the increase of the real exchange rate effective lei / euro by $3.3 \%$ in this period. Of the countries analyzed, only Poland and Hungary had a similar evolution, but the growth of the actual effective rate was lower (Poland: $2.57 \%$ and Hungary: 0.5\%). On the other hand, the Czech Republic registered a significant decrease in external competitiveness (the effective exchange rate of the crown / euro decreased by 9\%), while in Bulgaria it decreased slightly (the actual effective exchange rate of the euro / euro decreased by $0,4 \%$ ). 
On the other hand, if we analyze the evolution of competitiveness in 2018 compared to the previous year, it can be observed that in Romania the effective real exchange rate lei / euro decreased by $2.43 \%$, which is equivalent to a loss of competitiveness, due to the increase in domestic prices at a faster rate compared to external ones, an effect that was stronger than the nominal depreciation of the lei compared to the euro. Other countries who suffered losses of competitiveness in 2018 compared to 2017 are Bulgaria (-3.75\%), Slovakia (-2.08\%) and Poland $(-1.05 \%)$. On the other hand, the Czech Republic remains in the negative territory (decrease of the effective crown / euro effective rate of $4.3 \%$ ), but it presents an improvement of the situation compared to the evolution from 2014 to 2018.

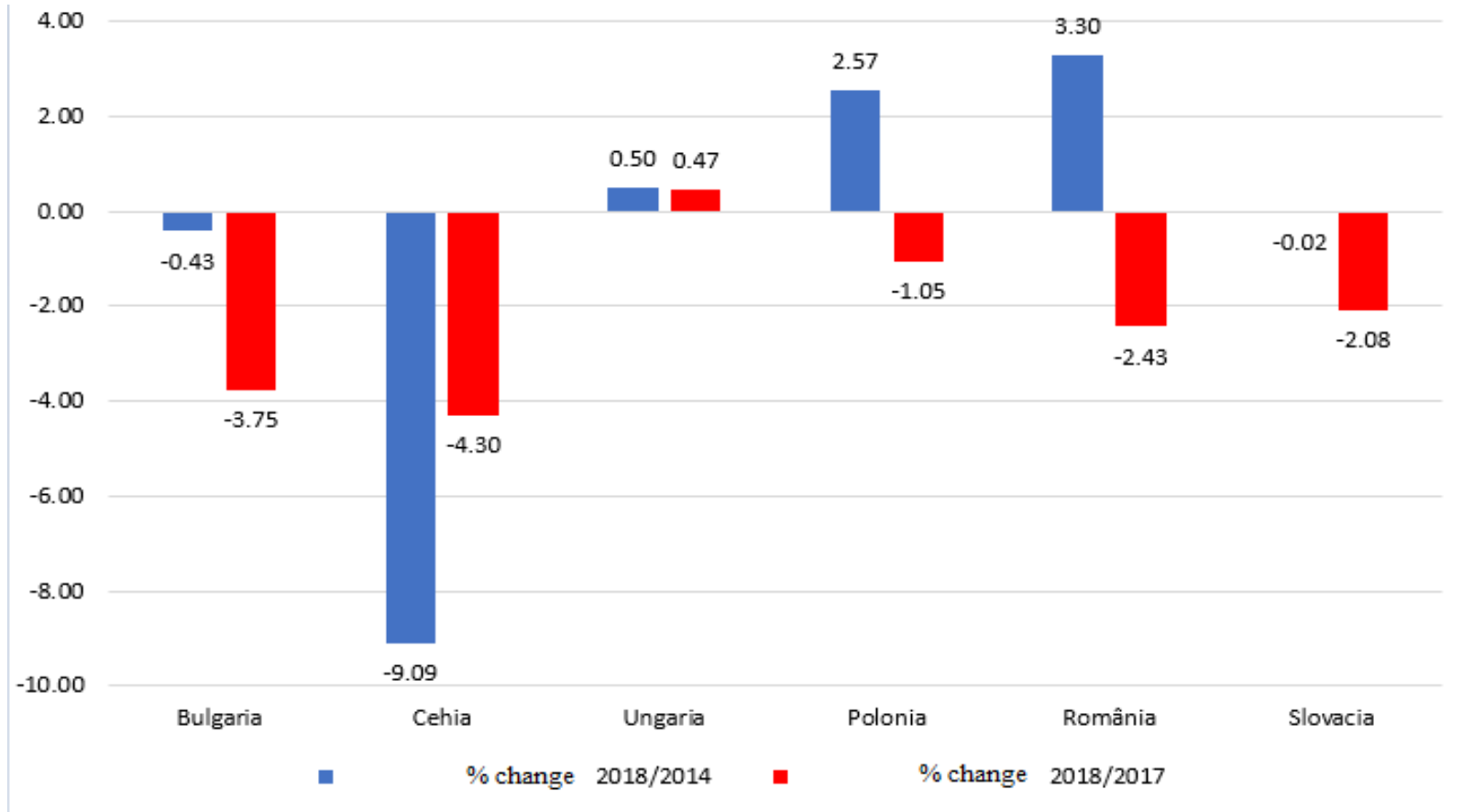

Graph 4: Evolution of the effective real exchange rate, national currency / euro (\%)

Data: Eurostat

\section{External risks:}

The international economic context is currently characterized by a series of risks, which have led to a slowdown in global economic expansion. These include mainly (i) trade tensions, especially between China and the US, but also possible future tariffs imposed on the European Union by the US for the import of motor vehicles; (ii) industry slowdown in Germany; (iii) vulnerabilities in the financial system caused by the high level of public and private debt etc.

Thus, the latest data reflects the continuation of a fragile evolution in the case of the manufacturing industry and international trade and in 2019, amidst the commercial tensions and growing economic uncertainty. In this context, international organizations have revised downward the forecast of economic growth.

As for the European economy, there is a more pronounced slowdown in the euro area, as it is more dependent on external demand, with net exports contributing massively to economic growth in recent years. Thus, for the first part of this year (the first quarter) the data already reflects a significant tempering of the economic growth in the Euro area at 1\% (compared to an advance of 
$1.4 \%$ in the fourth quarter of 2018), with insignificant values in the case of some big economies like those of Germany and France $(0.6 \%$, respectively 0.8$)$ and even a decrease in the case of Italy $(-0.3 \%)$ - these states being the main trading partners of Romania.

At the same time, the surveys of the business environment indicate the most pronounced deterioration after the year of 2013 of the confidence of the economic agents in the industry sector, evolution noticed mainly in Germany, state in which one of the most important decreases of the industrial production has materialized (-4.3\% in May 2019 compared to the similar month of last year and at the same time in comparison with the previous months).

This unfavorable evolution of European industry (especially in Germany - the engine of the European economy) does not seem to be temporary, and the escalation of trade tensions, including the imposition of US tariffs on car imports from the EU, may accentuate the decline of this sector and it increases the likelihood of additional risks at the level of employment, which, for the time being, remains stable. Already there are signs that employment in the manufacturing industry could be affected in the following period: company-level surveys indicate that employment intentions have worsened significantly over the similar period last year (mainly in Germany).

At the same time, there is a risk that the robust growth rate in the states of Central and Eastern Europe, including Romania, will slow down, due to the climate of uncertainty in the economies of the main trading partners. The Romanian economy, as part of the European economy, depends on the international economic context and, in particular, on the economic growth of the main trading partner countries.

Thus, the fact that over $70 \%$ of Romania's exports are oriented to the EU highlights the extent to which our country is exposed to fluctuations in foreign demand. The exports related to the auto industry to Germany represent about $15 \%$ of the total exports and about $10 \%$ of the country's GDP, our economy being very exposed to a slowdown in the German car industry.

\section{Conclusions and suggestions}

All the elements described confirm the need to maintain internal economic balances within appropriate limits, but also to reduce the uncertainty associated with the implemented policies. Thus, as policy recommendations, states with significant deficits should seek fiscal consolidation, encourage savings and boost competitiveness. At the same time, structural reforms should play a more important role in correcting external imbalances.

In order for the trade deficit not to lead to a depreciation of the leu, non-debt capital inflows are needed, preferably FDI and European investment funds. In parallel, they could solve the problem of Romania's low production capacity. In general, the current account deficit can be maintained at a sustainable level by encouraging the allocation of public and private funds to investments, and less to consumption, thus contributing to sustainable long-term economic growth.

In order to reduce the current account deficit, the following can be taken into account:

- Stimulating exports of long-term consumer goods, mainly by resuming structural reforms and increasing the competitiveness of the economy: in agriculture and industry by supporting the development of complete production chains and processing of domestic agricultural production into higher value-added finished products.

- Stimulating agricultural production would reduce or even eliminate the deficit of the balance of agri-food goods and can be achieved by:

1) the rehabilitation and modernization of the main irrigation infrastructure and the adoption of measures to manage risks in agriculture as a result of climate change 
2) stimulating the farmers' association, which would have multiple benefits: increasing economies of scale, facilitating access to irrigation systems, cooperating on short chains to jointly deliver agri-food products directly to supermarket chains, etc.

- Investments aimed at export-oriented sectors (tradable), such as the auto industry, chemicals, etc., while supporting the domestic sectors where there is a net negative export (agri-food products, pharmaceutical industry, tourism services, etc.).

PICBE $\mid 1003$

- Public investments in transport, energy and education infrastructure can increase the cost competitiveness of the entire economy and generate new economic opportunities, including attracting new foreign direct investments in export sectors. At the same time, investments in infrastructure would increase Romania's energy efficiency, which would lead to a reduction of fuel consumption and implicitly of oil imports.

- In addition, the increase of the energy efficiency can be realized by measures that determine the diminution of the energy consumption in the level of the households and at the level of the companies:

1) Implementing a long-term strategy for the energy rehabilitation of buildings

2) Promoting programs regarding the installation of heating systems using renewable energy (offering co-financing)

3) Reducing energy consumption at the company level through systematic audit, information actions on energy management and encouraging the activity of Energy Savings Companies (ESCO).

\section{References}

Avdjiev, S., Everett, M., Lane, P. R. \& Shin, H. S. (2018). Tracking the International Footprints of Global Firms. BIS Quarterly Review, March 2018, 47-66.

Barattieri, A. (2014). Comparative Advantage, Service Trade, and Global Imbalances. Journal of International Economics, 92 (1), 1-13.

Borio, Claudio \& Disyatat, Piti (2015). Capital flows and the current account: Taking financing (more) seriously. BIS Working Papers, No 525 (October 2015). Monetary and Economic Department.

Frenkel, Jacob, Razin, Assaf \& Yuen, Chi-Wa (1996). Fiscal Policies and Growth in the World Economy. Cambridge, MA: MIT.

Ghosh, A. \& Ramakrishnan, U. (2012). Current Account Deficits: Is There a Problem?. Finance and Development, March. International Monetary Fund.

Ghosh, Atish (1995). International Capital Mobility Amongst the Major Industrialised Countries: Too Little or Too Much?. The Economic Journal, 105, 107-128.

Glick, Reuven \& Rogoff, Kenneth (1995). Global versus Country-Specific Productivity Shocks and the Current Account. Journal of Monetary Economics, 35, 159-192.

IMF (2009). Balance of Payments and International Investment Position Manual ( $6^{\text {th }}$ ed.). (BPM6). Washington, DC: IMF.

Knight, Malcom \& Scacciavillani, Fabio (1998). Current accounts: what is their relevance for economic policymaking?. International Monetary Fund, May 1998.

Obstfeld, Maurice \& Rogoff, Kenneth (1995). The Intertemporal Approach to the Current Account. In Grossman, G., Rogoff, K. (eds.). Handbook of International Economics, Vol. 3. Amsterdam: North Holland.

Obstfeld, Maurice \& Rogoff, Kenneth (1996). Foundations of International Macroeconomics. Cambridge, MA: MIT. 
Sachs, Jeffrey (1981). The Current Account and Macroeconomic Adjustment in the 1970s. Brookings Papers on Economic Activity, 1, 201-282.

PICBE | 1004 